\title{
CHARACTERIZING NUTRIENT DISTRIBUTIONS AND FLUXES IN A EUTROPHIC RESERVOIR, MIDWESTERN UNITED STATES
}

\section{Alexandra R. Pearce ${ }^{\mathrm{a}{ }^{*}}$, Lisa G. Chambers ${ }^{\mathrm{b}}$, Elizabeth A. Hasenmueller ${ }^{\mathrm{a}}$}

${ }^{\mathrm{a}}$ Saint Louis University, Department of Earth and Atmospheric Sciences, O'Neil Hall, 3642 Lindell Blvd, Saint Louis, Missouri, 63108, USA

${ }^{\mathrm{b}}$ University of Central Florida, Department of Biology, Biological Sciences Bldg., 4110 Libra Drive, Orlando, Florida, 32816, USA

*Corresponding author, email: alexandra.pearce@student.nmt.edu, +1-717-412-8398

${ }^{1}$ Present address:

New Mexico Institute of Mining and Technology, Earth \& Environmental Science Department, 801 Leroy Place, Socorro, New Mexico, 87801, USA 


\begin{abstract}
Harmful algal blooms are increasingly common in aquatic ecosystems and have been linked to runoff from agricultural land. This study investigated the internal nutrient (i.e., phosphorus (P) and nitrogen $(\mathrm{N})$ ) dynamics of a eutrophic reservoir in the Midwestern United States to constrain the potential for sedimentary nutrients to stimulate harmful algal blooms. The spatial distribution of nutrients in the water column (soluble reactive $\mathrm{P}(\mathrm{SRP})$, nitrate/nitrite- $\mathrm{N}\left(\mathrm{NO}_{\mathrm{x}}-\mathrm{N}\right)$, and ammonium-N $\left(\mathrm{NH}_{4}{ }^{+}-\mathrm{N}\right)$ ) and sediments (total $\mathrm{P}$, total carbon $(\mathrm{C})$, total $\mathrm{N}$, and organic matter $(\mathrm{OM})$ ) were quantified and mapped. Water column nutrients varied spatially and temporally, with generally higher concentrations near the dam wall during normal lake levels. The upper portion of the lake, near the inlet, was sampled during a flood event and had overall higher nutrient concentrations and lower chlorophyll levels compared to normal lake level samples. Mean sediment total P $(936 \mathrm{mg} / \mathrm{kg}$ ) was $\sim 30 \%$ higher in the reservoir than the surrounding upland soils, with the highest concentrations near the dam wall $(1,661 \mathrm{mg} / \mathrm{kg})$ and a significant positive correlation found between sediment total $\mathrm{P}$, total C, and OM. Additionally, 15 intact sediment cores were manipulated ex situ to examine mechanisms of nutrient flux across the sediment-water interface (SWI) that may trigger algal blooms. Core treatment conditions included advection (i.e., simulating potential nutrient fluxes during wind events through sediment resuspension) and diffusion. Core experiments indicated both advective and diffusive conditions at the SWI may trigger the flux of nutrients important for algal growth from lake sediments, with diffusion contributing both $\mathrm{N}$ and $\mathrm{P}$ to the water column, while intense advection increased water column N, but decreased P. Release of $\mathrm{P}$ to the water column may be more diffusion-driven than advection-driven, whereas $\mathrm{N}$ release to the water column appears to be both diffusion- and advection-driven.
\end{abstract}

Keywords: water quality, nutrient loading, reservoir, diffusion, sediment resuspension, algal blooms 


\section{Introduction}

Globally, intensive agriculture has been linked to eutrophication, declining water quality, and algal blooms, resulting in more than $\$ 2$ billion in annual damage in the United States alone (Paerl et al., 2011). Algal blooms are triggered by excess inputs of the normally limiting nutrients nitrogen $(\mathrm{N})$ and phosphorus $(\mathrm{P})$, and can be responsible for a range of human health and environmental risks, from liver toxic Microcystis blooms in Lake Erie (Kane et al., 2014) to the expanding Dead Zone in the Gulf of Mexico (Yaeger et al., 2013). Harmful algal blooms are predicted to increase in magnitude and frequency, exacerbated by increasing pollution and climate change (Paerl et al., 2011; Paerl and Paul, 2012). Systems vulnerable to harmful blooms include lakes and reservoirs, particularly those in highly agricultural areas. River impoundments may affect watershed-scale biogeochemical processes (Powers et al., 2013): eutrophic reservoirs have been shown to be sites of $\mathrm{N}$ loss and co-occurring $\mathrm{P}$ storage (David et al., 2006; Grantz et al., 2014). Extensive denitrification in large, shallow reservoirs may be beneficial, leaving less $\mathrm{N}$ to contribute to downstream hypoxia. However, large impoundments may not be enough to mitigate downstream hypoxia, and $\mathrm{N}$ pollution is problematic for reservoirs (David et al., 2006).

Accumulated $\mathrm{P}$ in the sediments may result in a system of self-perpetuating eutrophication through endogenous loading of stored P (Reddy et al., 1996; Grantz et al., 2014). Significant P loading from sediments has been observed in environments as diverse as estuarine (Roy et al., 2012), boreal (Tammeorg et al., 2015), and subtropical (Xie et al., 2003; Grunwald et al., 2006; Torres et al., 2014), and in bodies of water as large as the North American Great Lakes (Kane et al., 2014) and Lake Taihu in China (You et al., 2007). Excess P inputs are often stored in lentic systems as "legacy" P (Sharpley et al., 2013), which is P that has been accumulating in sediments over time and may take tens to thousands of years to flux out of the system (Kleinman 
et al., 2011a). Algal blooms fed by internally stored P fluxing into the water column would not be affected by nutrient runoff mitigation and could continue in near-perpetuity, as reflected by some systems that have naturally high P inputs (e.g. Kilinc and Moss, 2002). In fact, algae like Mycrosistis can stimulate $\mathrm{P}$ release from the sediments through raising water column $\mathrm{pH}$ via photosynthesis (Xie et al., 2003).

Important mechanisms for internal loading in lentic systems are diffusive and advective processes (Reddy and Newman, 1992; Roy et al., 2012; Tammeorg et al., 2015). In detail, eutrophic systems can lead to bottom water anoxia that triggers $\mathrm{P}$ release due to reduction of iron (Fe)-bearing minerals. Moreover, water columns depleted of nutrients from high levels of primary productivity in summer may drive molecular diffusion of nutrients from sediments into the water column (Einsele, 1936; Mortimer, 1941; Amirbahman et al., 2003; Amirbahman et al., 2012). In terms of advection (defined here as the transport of sediments and porefluids from the lakebed to the water column via sediment resuspension), P dynamics in shallow lacustrine environments have been shown to be wind-driven (e.g., Søndergaard et al., 1992; Zhang et al., 2011) due to wind-induced wave action causing shear on the bed sediments (Ding et al., 2012). This may result in bioavailable soluble reactive phosphorus (SRP) desorption from suspended sediment particles as a response to lower water column P levels or SRP release from enriched sediment porewaters. By increasing shear stress on the sediment, more bioavailable P may be released depending on the composition of the sediment (Dorich et al., 1985; Moore and Reddy, 1994). Indeed, hurricanes, accompanied by intense storms and large shear stresses at the sediment-water interface (SWI), have been reported to stimulate SRP upwelling in lakes and wetlands (Ding et al., 2012; Dunne et al., 2012). 
We examined patterns of nutrient loading and storage in Carlyle Lake, Illinois, USA, an impacted agricultural reservoir in the Mississippi River watershed in which harmful algal blooms have been observed, to determine if conditions favorable for algal blooms could be triggered by internal loading alone. This study seeks to answer the following questions: What are the concentrations and spatial distributions of sedimentary and surface water nutrient pools in a shallow reservoir surrounded by intensive agricultural land use, and what drives the exchange of nutrients between the sediments and water column: advective or diffusive flux? By constraining the distribution of the endogenous nutrient load and dominant mechanism of nutrient flux, this study seeks to inform reservoir management for improved remediation of nutrient pollution and the concomitant algal blooms and hypoxia that threaten water security.

\section{Site Description}

Carlyle Lake is the lower of two large impoundments along the Kaskaskia River, which drains central Illinois, USA, and eventually flows into the Mississippi River. The Kaskaskia River watershed is $14,152 \mathrm{~km}^{2}$ of predominantly agricultural land (i.e., $67 \%$; Chiang et al., 2012). The upper Kaskaskia River watershed has extensive tile drainage, which conduits nutrient-rich runoff to waterbodies (David et al., 2006; Yaeger et al., 2013). Carlyle Lake was dedicated in 1967, and is managed by the US Army Corps of Engineers for flood control purposes (Illinois State Water Survey, 1975), drinking water supply, and recreation. It is large and generally shallow $\left(105 \mathrm{~km}^{2}\right.$; mean depth $=3.4 \mathrm{~m}$; Illinois Department of Natural Resources, 2016), with two distinct sections divided by a railway trestle: a much shallower (mostly $<1 \mathrm{~m}$ ) northern portion (referred to here as the "upper lake") below the Kaskaskia River inlet, which features partially submerged trees, and a larger, deeper, and southern portion (referred to as the "lower lake") that extends below the railway to the dam wall. Carlyle Lake can experience high 


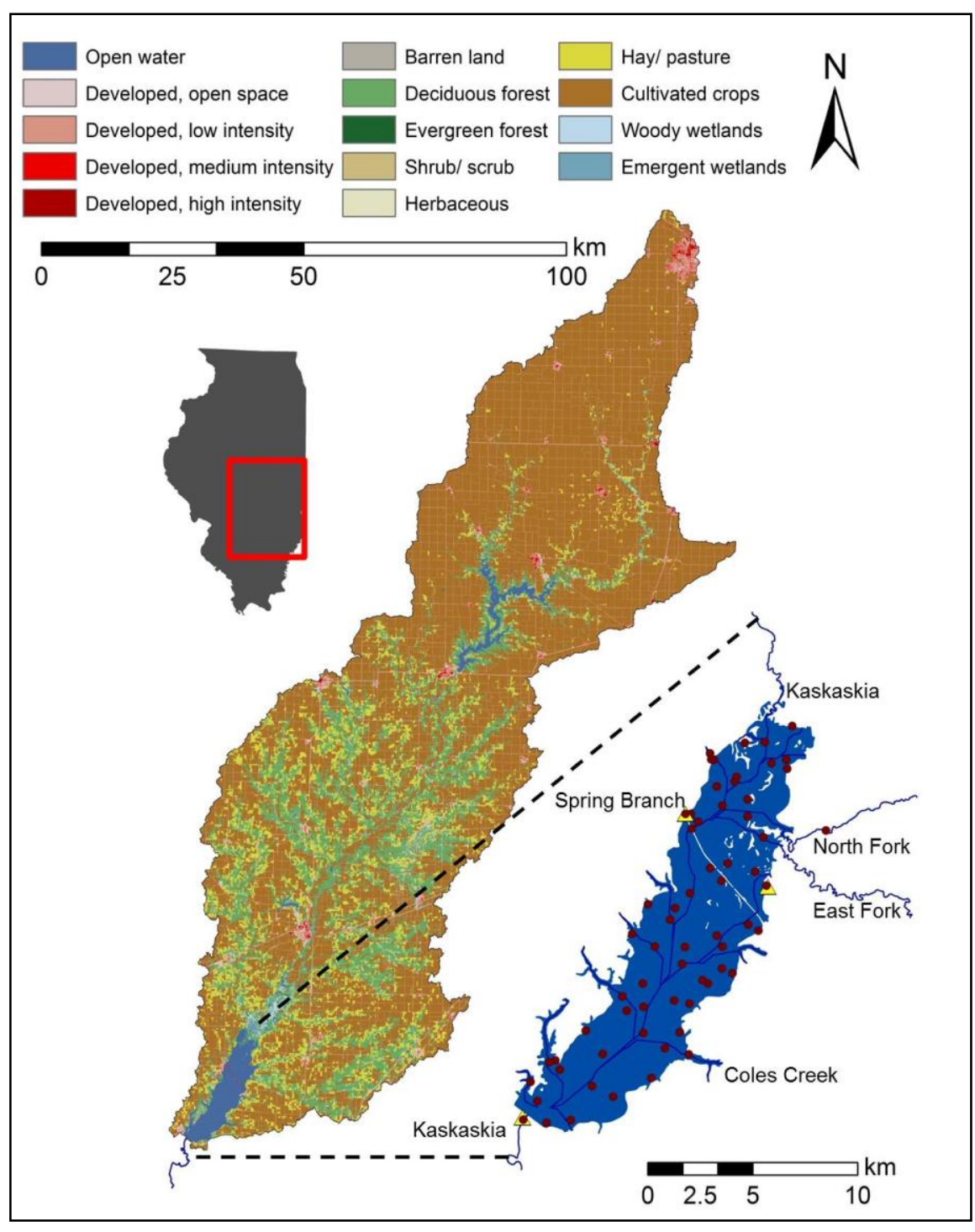

Figure 1. Site map showing Carlyle Lake's drainage area $\left(7,030 \mathrm{~km}^{2}\right)$ and land cover classification. Approximately $73 \%$ of the land cover is agricultural (i.e., cultivated crops and hay/pasture). Note the presence of two reservoirs in the drainage area: Lake Shelbyville in the north and Carlyle Lake (expanded with important tributaries labeled) in the south. Red circles show sampling locations of waters and sediments and yellow triangles represent upland sample locations where we collected soils. The railway trestle dividing the lake is shown as a white line, starting just below the Spring Branch tributary. winds and waves due its large

fetch. The size and highly

agricultural setting of the lake's

drainage area $\left(7,030 \mathrm{~km}^{2} ; 73 \%\right.$

farmland; Fig. 1) has likely led to

the observed high levels of $\mathrm{P}$ in

Carlyle Lake's water column

(e.g., US Army Corps of

Engineers, 2006), above the

Illinois General Use Water

Quality Standard for total P in

lakes (i.e., 0.05 ppm; Illinois

Environmental Protection

Agency, 2016). The lake's

compromised quality is

evidenced by anecdotal reports

of fish kills and algal blooms,

both of which were observed on

the shores of the upper lake

during sampling for this study.

\section{Methods}

\subsection{Field Sampling}

To understand the distribution of nutrients within Carlyle Lake, we collected an extensive 
and high resolution suite of water and sediment samples. Sampling sites were randomly generated in ArcMap 10.1 using a random raster probability surface, and accessed by boat on 4-6 May 2015 and 9 June 2015. The first sampling period was focused on the lower lake with some samples collected at upper lake boat docks. The second sampling period was during flooding conditions when the upper lake was boat-accessible. In situ water quality parameters (dissolved oxygen (DO), $\mathrm{pH}$, specific conductivity, turbidity, and chlorophyll concentration) were measured at each sampling site using a YSI 6600V2 or EXO2 sonde (Yellow Springs Instruments, Yellow Springs, Ohio) and a Hach Turbidimeter (Hach Company, Loveland, Colorado). Water samples for nutrient analysis (SRP, nitrate/nitrite-N $\left(\mathrm{NO}_{\mathrm{x}}-\mathrm{N}\right)$, and ammonium- $\left.\mathrm{N}\left(\mathrm{NH}_{4}{ }^{+}-\mathrm{N}\right)\right)$ were taken from the lake surface ("surface water") and close to the SWI ("bottom water") using a Van Dorn water sampler. Samples were stored in acid-washed polyethylene bottles on ice until reaching the lab, whereupon they were filtered through $0.45 \mu \mathrm{m}$ filters into $20 \mathrm{~mL}$ scintillation vials, preserved with sulfuric acid $(\mathrm{pH}<2)$, and stored at $4^{\circ} \mathrm{C}$ until analysis. Sediments for total $\mathrm{P}$, total carbon $(\mathrm{C})$, total $\mathrm{N}$, and organic matter $(\mathrm{OM})$ analyses were collected using a Petite Ponar grab sampler (Wildco, Yulee, Florida). The upper $5 \mathrm{~cm}$ of sediment was transferred to ziplock bags using a marked trowel and stored on ice until reaching the lab; samples were then refrigerated at $4{ }^{\circ} \mathrm{C}$ until analysis. A total of 67 discrete sampling locations in the lake body were utilized for the spatial study, and where possible, surface water, bottom water, and sediment samples were collected at these locations. This resulted in 61 sediment samples, 64 surface water samples, and 62 bottom water samples. Additionally, two tributaries were sampled for surface water (i.e., the North Fork and Kaskaskia River below the dam). We also sampled three upland soils around the lake (Fig. 1) for total $\mathrm{P}$, total $\mathrm{C}$, and total $\mathrm{N}$ as a coarse comparison to lake sediment. 
To assess the role of advective and diffusive flux in nutrient dynamics along the SWI, 20 intact sediment cores of varying lengths $(8-15 \mathrm{~cm})$ were collected from a cove near the West Branch tributary (chosen due to logistical constraints based on water levels as a generally representative site for the lake as a whole) (Fig. 1). Cores were collected on 29 July 2015 using a manual piston corer (Fisher et al., 1992) fitted with $46 \mathrm{~cm}$ long and $7 \mathrm{~cm}$ diameter acrylic core tubes. Cores were topped with lake water to minimize sediment oxidation, sealed with rubber stoppers and duct tape, and stored upright prior to returning to the lab. Lake water was collected near the coring site nine days before core samples were obtained, and stored in an opaque carboy to prevent photosynthesis-induced changes in nutrients.

\subsection{Lake water and sediment characterization}

Surface and bottom water samples from Carlyle Lake were colorimetrically analyzed (US Environmental Protection Agency, 1993) for SRP (method detection limit (MDL): 0.002 ppm), $\mathrm{NO}_{\mathrm{x}}-\mathrm{N}$ (MDL: $0.005 \mathrm{ppm}$ ), and $\mathrm{NH}_{4}{ }^{+} \mathrm{N}$ (MDL: $0.004 \mathrm{ppm}$ ) on a Seal AQ2 Discrete Analyzer (Seal Analytical Limited, Mequon, Wisconsin). For all analyses on the AQ2, blank samples, duplicates, and duplicate samples 'spiked' with a known concentration of a nutrient were run every 10 samples. Analytical error was within $\pm 20 \%$. We followed the method of Anderson (1976) to determine total sedimentary P. Briefly, dried, ground subsamples were combusted $\left(250^{\circ} \mathrm{C}\right.$ for 30 minutes, then $3 \mathrm{~h}$ at $\left.550^{\circ} \mathrm{C}\right)$, followed by boiling in $6 \mathrm{~N} \mathrm{HCl}$ on a hot plate (converting sample P to SRP), and measurement of the supernatant on an AQ2 for SRP. We determined OM content through loss-on-ignition during the total sedimentary P processing step where samples were combusted. Total $\mathrm{C}$ and total $\mathrm{N}$ were measured on dried and ground subsamples using an Elemental Combustion System (Costech Analytical Technologies, Valencia, California). 


\subsection{Spatial Interpolation and Analysis}

Carlyle Lake's drainage area was delineated in ArcMap 10.1 to determine percent land cover from crop data (US Department of Agriculture, 2000, US Department of Agriculture, 2015). Inverse distance weighting (IDW) interpolation was used to generate surfaces of a given parameter from georeferenced data in ArcMap using the Geostatistical Analyst extension clipped to Carlyle Lake's shapefile (US Environmental Protection Agency, 2014). IDW is a deterministic method where assigned values to unknown points are calculated with a weighted average of known points (Li and Heap, 2008).

\subsection{Core Study}

A total of 20 cores were used to determine nutrient flux dynamics across the SWI in lab experiments. The day following core collection in the field, 15 of the cores were randomly split into three groups of five replicates and were treated to mimic the effects of advection through stimulated storm pulses inducing sediment resuspension ("agitation" group) on a water column of lake water, molecular diffusive flux on a water column of lake water ("site water diffusion" group), and molecular diffusive flux on a water column of nutrient-free distilled deionized (DI) water ("DI diffusion" group) to simulate flux to a depleted water column that might occur under conditions of high primary productivity. The remaining five cores were split into $0-5 \mathrm{~cm}$ and $5+$ $\mathrm{cm}$ intervals, transferred to ziplock bags, and refrigerated at $4{ }^{\circ} \mathrm{C}$ until analysis a week after collection for sedimentary total P, total N, and total C, and $\mathrm{KCl}$-extractable $\mathrm{N}$ and SRP to characterize the untreated sediments and act as a proxy for pre-experimental conditions.

Prior to the experiment, core water columns added in the field were slowly poured off in the lab and replaced with a $10 \mathrm{~cm}$ water column corresponding to treatment type, then core tubes were capped with rubber stoppers. The cores were then stored upright at room temperature (22- 
$25^{\circ} \mathrm{C}$, compared to average lake temperatures of $21.8^{\circ} \mathrm{C}$ ) in light free conditions to inhibit photosynthesis. The agitation group was treated with simulated storm pulses in a shaker over 29 d as follows: 1) $5 \mathrm{~d}$ shaken at $195 \mathrm{rpm}$, mimicking an extreme wind storm, 2) $12 \mathrm{~d}$ of no agitation to represent a period of quiescence, 3) $5 \mathrm{~d}$ shaken at $65 \mathrm{rpm}$ after an initial $2 \mathrm{~h}$ at $165 \mathrm{rpm}$, mimicking the progression of a less severe storm event, and 4) $5 \mathrm{~d}$ of no agitation to represent a second period of quiescence. Diffusion cores were observed for a $22 \mathrm{~d}$ period. Stored lake water used as replacement water was periodically run for nutrients to monitor changes in chemistry.

For each treatment type, sampling frequency progressively decreased from the onset of the treatment, decreasing from hourly to weekly intervals. Water samples were pipetted in equal volumes from the top, middle, and near-SWI in the water column $(9 \mathrm{~mL}$ total) and passed through a $0.45 \mu \mathrm{m}$ syringe filter, then stored in scintillation vials at $4^{\circ} \mathrm{C}$. Analysis for $\mathrm{SRP}, \mathrm{NO}_{\mathrm{x}^{-}}$ $\mathrm{N}$, and $\mathrm{NH}_{4}{ }^{+}-\mathrm{N}$ occurred within $12 \mathrm{~h}$ of sample collection on the AQ2 in the manner described in Section 3.2. Due to the potential for redox changes in $\mathrm{N}$ species, we also examined the combined concentrations of $\mathrm{NO}_{\mathrm{x}}-\mathrm{N}$ and $\mathrm{NH}_{4}{ }^{+}-\mathrm{N}$ (referred to here as "total dissolved $\mathrm{N}$ species") throughout the experiment. Any changes in water column $\mathrm{pH}, \mathrm{DO}$, conductivity, and temperature were measured in situ using a YSI ProPlus (Yellow Springs Instruments, Yellow Springs, Ohio) during sample collection. Due to sample volume limitations, we measured water turbidity with a Hach Turbidometer rather than total suspended solids (TSS). A turbidity-TSS relationship curve was developed for this study by measuring the turbidity of mixtures with known amounts of untreated core sediments and ambient lake water. This eliminated the need to perform TSS analysis on treated cores throughout the experiment. Due to instrument malfunctions, we were unable to sample individual replicates on days 6-17 of the experiment, and samples had to be acidified and composited for the five replicates within each treatment group during this time. 
To determine if the sediment-sorbed and porewater nutrient $\mathrm{N}$ and $\mathrm{P}$ pools were affected by the treatment conditions, treated core sediments were destructively analyzed after the $29 \mathrm{~d}$ experiment for KCl-extractable SRP (MDL: $0.04 \mathrm{ppm}$ ), $\mathrm{NO}_{\mathrm{x}}-\mathrm{N}$ (MDL: $0.015 \mathrm{ppm}$ ), and $\mathrm{NH}_{4}{ }^{+}-\mathrm{N}$ (MDL: $0.04 \mathrm{ppm}$ ) and were compared to the untreated cores. In detail, cores were split into 0-5 $\mathrm{cm}$ and $5+\mathrm{cm}$ (up to $10 \mathrm{~cm}$ ) segments and homogenized in order to compare nutrient content in sediments at the SWI, which have been shown to be most active in terms of interaction with the water column (Qin et al., 2004), to deeper sediment nutrient pools. Approximately $11 \mathrm{~g}$ of sediment was shaken with $100 \mathrm{~mL}$ of $2 \mathrm{M} \mathrm{KCl}$ for $1 \mathrm{~h}$, the solution was filtered through Whatman no. 1 filter paper, and the supernatant run on an AQ2 (US Environmental Protection Agency, 1993). Additionally, the total P, total C, total N, and OM for each treated core were analyzed as described in Section 3.2. Sedimentary metal levels (Fe, calcium $(\mathrm{Ca})$, and aluminum (Al)) were analyzed via Inductively Coupled Plasma Optical Emission Spectrometry (ICP-OES; Perkin-Elmer Optima 7300DV; Waltham, Massachusetts) using supernatant from the total P method. Sedimentary metal levels were used as a proxy for mineralogical analysis. Replicates were run every 10 samples; the relative standard deviation was within $\pm 5 \%$.

\subsection{Statistical Analyses}

Statistical analyses were performed in R 2.14.2 with Hsmic package cor() and rcorr() functions to compute Pearson correlations with significance levels set at $\mathrm{p}<0.05$ (R Core Team 2016). Microsoft Excel was used to compute linear regressions, analyses of variance (ANOVA), repeat measures (RM)-ANOVA, and paired t-tests for means. 


\section{Results}

\subsection{Spatial Distribution of Nutrients in Water and Sediments}

Generally, water column nutrient concentrations were lowest in the lake during May sampling when the water level was low, and highest in the upper lake during June flooding (Fig. 2; note that the May upper lake interpolation relies on data from five sampling locations: four along the shoreline and one beside the railway). The higher SRP and $\mathrm{NO}_{\mathrm{x}}-\mathrm{N}$ during the June sampling event coincided with lower mean specific conductivity during the flood pulse (416 $\mu \mathrm{S} / \mathrm{cm}$ in May versus $263 \mu \mathrm{S} / \mathrm{cm}$ in June). In contrast to the nutrient levels, mean chlorophyll levels were higher in May than in June (25 ppb and $15 \mathrm{ppb}$, respectively). Nutrient and chlorophyll concentrations were generally homogenous (i.e., $p>0.05$ ) with water column depth, with the exception of May SRP and June $\mathrm{NH}_{4}{ }^{+}-\mathrm{N}$ levels, which were higher in bottom waters (p $<0.05$ ), especially near the dam wall (Fig. 2).

The total $\mathrm{P}$ in lake sediments generally increased from the north (i.e., the lake inlet) to the south (i.e., the dam wall). Mean sedimentary total P was $936 \mathrm{mg} / \mathrm{kg}$, with the highest levels (up to $1,661 \mathrm{mg} / \mathrm{kg}$ ) occurring near the dam wall in the deepest portions of the lake (Fig. 3) and the lowest levels near the lake's northeastern tributaries (i.e., $138-800 \mathrm{mg} / \mathrm{kg}$ ). The mean total $\mathrm{P}$ in lake sediments was high compared to that of three upland soil samples collected near the lake (average: $648 \mathrm{mg} / \mathrm{kg}$; locations shown in Figs. 1, 3). 

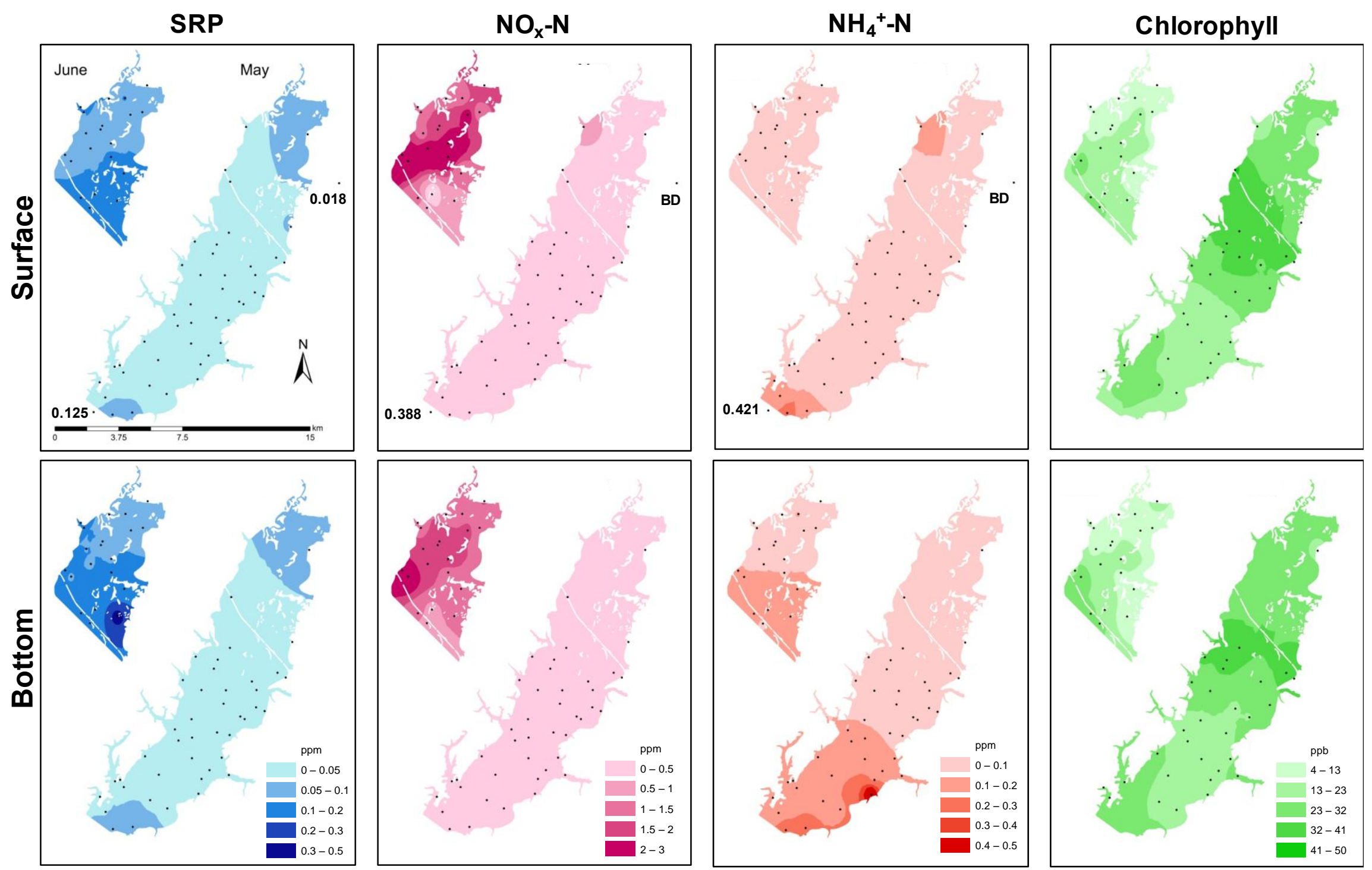

Figure 2. Interpolated maps of Carlyle Lake's SRP (blue), $\mathrm{NO}_{\mathrm{x}}-\mathrm{N}$ (pink), $\mathrm{NH}_{4}{ }^{+}-\mathrm{N}$ (orange), and chlorophyll (green) levels. Maps on the top row are of surface water samples, while bottom row maps are of water samples collected near the SWI. Interpolations for the two sampling periods (i.e., May and June) are also shown for each parameter and depth (i.e., June data on the left and May data on the right of each box). Black circles indicate sampling locations. For each of the May water quality maps, two points fall outside the lake body and represent water samples taken at the North Fork tributary and downstream of the reservoir on the Kaskaskia River; neither was used for interpolation as they were not collected directly from the reservoir. Their respective nutrient values are annotated, where BD is below detection. Also note that the May upper lake interpolation relies on data from five sampling locations. 
Sedimentary total $\mathrm{C}$ and $\mathrm{OM}$ distributions across the lake were generally similar to total $\mathrm{P}$, with higher concentrations towards the southern portions of the lake near the dam wall. In contrast, the highest total $\mathrm{N}$ concentrations were encountered in the upper lake (Fig. 3), extending
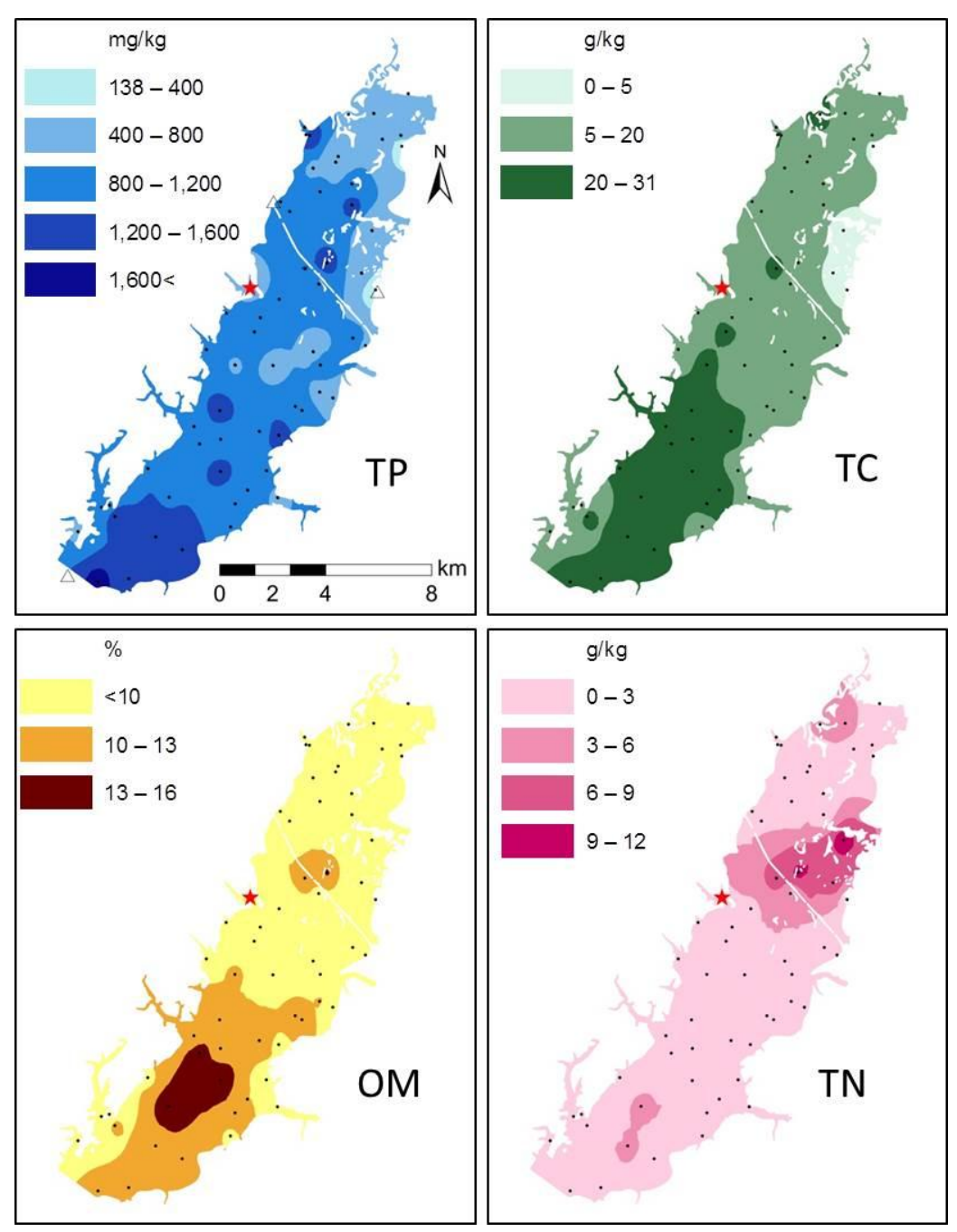

Figure 3. Interpolation maps of Carlyle Lake's sedimentary total P (TP), total C (TC), OM, and total N (TN) taken from the top $5 \mathrm{~cm}$ of lake sediments. Black circles show the lake sampling locations. The red star marks where intact sediment cores were collected for the core study. Open triangles on the total P map mark where upland soil samples were collected. southwestwards from the North

Fork and East Fork tributaries.

Upland soil samples exhibited

higher mean levels of total C

$(30.50 \mathrm{~g} / \mathrm{kg}$ ) and similar total $\mathrm{N}$

and $\mathrm{OM}$ concentrations $(2.17 \mathrm{~g} / \mathrm{kg}$

and $9.64 \%$, respectively)

compared to lake sediments (lake

mean total $\mathrm{C}$, total $\mathrm{N}$, and $\mathrm{OM}$ :

$16.32 \mathrm{~g} / \mathrm{kg}, 2.38 \mathrm{~g} / \mathrm{kg}$, and $8.50 \%$,

respectively).

\section{Based on Pearson}

correlations of sediment and water

data, there are several significant

relationships (Table 1). For

sediments, total P was highly

correlated with sedimentary total

C content and OM ( $\mathrm{p}<0.001)$.

Water depth was positively correlated to total $\mathrm{P}(\mathrm{p}=0.005)$ and total $\mathrm{C}(\mathrm{p}<0.001)$. Total $\mathrm{C}$ and

OM levels were found to be significantly $(\mathrm{p}<0.001)$ lower in the upper lake compared to the 
lower lake. For lake waters, $\mathrm{pH}$ and DO were negatively correlated with both surface and bottom water SRP and $\mathrm{NO}_{\mathrm{x}}-\mathrm{N}$ concentrations $(\mathrm{p}<0.001)$ and with surface $\mathrm{NH}_{4}{ }^{+}-\mathrm{N}(\mathrm{p}<0.001)$.

Dissolved nutrient concentrations were inversely proportional to chlorophyll levels $(\mathrm{p}<0.001)$, with the exception of bottom water $\mathrm{NH}_{4}{ }^{+}-\mathrm{N}$. Turbidity levels were positively correlated with $\operatorname{SRP}(\mathrm{p}<0.001)$ and $\mathrm{NO}_{\mathrm{x}}-\mathrm{N}(\mathrm{p}<0.001)$. 
Table 1. Pearson correlation coefficients $(r)$ for sediment and water parameters. Parameters are abbreviated as follows: TP: total P, TN: total N, TC: total C, SPC: specific conductivity, Turb: turbidity, and Chlor: chlorophyll. Prefixes $s$ and $b$ refer to surface and bottom water samples, respectively. Colors indicate significant $p$-values, where green is $p<0.001$, blue is $p<0.01$, yellow is $p<$ 0.05 , and no color is $\mathrm{p}>0.05$.

\begin{tabular}{|c|c|c|c|c|c|c|c|c|c|c|c|c|c|c|c|c|c|c|c|c|}
\hline TP & TP & TN & TC & OM & Depth & sSRP & bSRP & $\mathrm{sNO}_{\mathrm{x}}$ & $\mathrm{bNO}_{\mathrm{x}}$ & $\mathrm{SNH}_{3}$ & $\mathrm{bNH}_{3}$ & SSPC & sDO & spH & sTurb & sChlor & bSPC & bDO & bpH & bTurb \\
\hline TN & 0.14 & & & & & & & & & & & & & & & & & & & \\
\hline TC & 0.71 & 0.09 & & & & & & & & & & & & & & & & & & \\
\hline OM & 0.70 & 0.24 & 0.82 & & & & & & & & & & & & & & & & & \\
\hline Depth & 0.36 & -0.02 & 0.51 & 0.51 & & & & & & & & & & & & & & & & \\
\hline sSRP & -0.16 & 0.31 & -0.38 & -0.31 & -0.56 & & & & & & & & & & & & & & & \\
\hline bSRP & -0.08 & 0.44 & -0.32 & -0.16 & -0.30 & 0.76 & & & & & & & & & & & & & & \\
\hline $\mathrm{sNO}_{\mathrm{x}}$ & -0.06 & -0.03 & -0.23 & -0.22 & -0.58 & 0.73 & 0.48 & & & & & & & & & & & & & \\
\hline $\mathrm{bNO}_{\mathrm{x}}$ & -0.06 & 0.10 & -0.20 & -0.16 & -0.60 & 0.79 & 0.52 & 0.95 & & & & & & & & & & & & \\
\hline $\mathrm{sNH}_{3}$ & 0.38 & 0.26 & 0.23 & 0.18 & 0.02 & 0.39 & 0.29 & 0.15 & 0.25 & & & & & & & & & & & \\
\hline $\mathrm{bNH}_{3}$ & 0.12 & 0.12 & 0.13 & 0.17 & 0.07 & 0.04 & 0.10 & 0.02 & 0.04 & 0.25 & & & & & & & & & & \\
\hline sSPC & 0.13 & -0.28 & 0.27 & 0.18 & 0.64 & -0.50 & -0.46 & -0.47 & -0.55 & -0.07 & -0.03 & & & & & & & & & \\
\hline sDO & 0.14 & -0.22 & 0.30 & 0.26 & 0.54 & -0.90 & -0.64 & -0.80 & -0.86 & -0.35 & -0.09 & 0.57 & & & & & & & & \\
\hline $\mathrm{spH}$ & 0.07 & -0.21 & 0.27 & 0.23 & 0.48 & -0.85 & -0.63 & -0.77 & -0.81 & -0.37 & -0.17 & 0.49 & 0.92 & & & & & & & \\
\hline sTurb & -0.27 & 0.12 & -0.38 & -0.36 & -0.68 & 0.70 & 0.50 & 0.70 & 0.77 & 0.08 & -0.02 & -0.76 & -0.81 & -0.79 & & & & & & \\
\hline sChlor & 0.11 & -0.13 & 0.09 & 0.10 & 0.22 & -0.51 & -0.41 & -0.37 & -0.42 & -0.42 & -0.16 & 0.26 & 0.67 & 0.62 & -0.46 & & & & & \\
\hline bSPC & 0.23 & -0.30 & 0.42 & 0.35 & 0.69 & -0.71 & -0.59 & -0.64 & -0.66 & -0.17 & 0.02 & 0.92 & 0.75 & 0.74 & -0.87 & 0.50 & & & & \\
\hline bDO & 0.01 & -0.28 & 0.22 & 0.13 & 0.50 & -0.89 & -0.67 & -0.83 & -0.88 & -0.36 & -0.10 & 0.67 & 0.93 & 0.92 & -0.81 & 0.63 & 0.77 & & & \\
\hline bpH & 0.04 & -0.26 & 0.30 & 0.20 & 0.47 & -0.87 & -0.67 & -0.77 & -0.82 & -0.48 & -0.19 & 0.68 & 0.93 & 0.99 & -0.79 & 0.70 & 0.73 & 0.94 & & \\
\hline bTurb & -0.32 & 0.04 & -0.45 & -0.42 & -0.64 & 0.63 & 0.41 & 0.61 & 0.63 & 0.09 & -0.07 & -0.74 & -0.70 & -0.65 & 0.82 & -0.49 & -0.76 & -0.69 & -0.64 & \\
\hline bChlor & -0.03 & -0.26 & 0.03 & -0.09 & 0.14 & -0.54 & -0.49 & -0.43 & -0.46 & -0.38 & -0.18 & 0.50 & 0.63 & 0.65 & -0.56 & 0.79 & 0.51 & 0.66 & 0.67 & -0.33 \\
\hline
\end{tabular}




\subsection{Core Study}

Initially, nutrient concentrations were similar in the advection and site water cores as both were treated with site water (i.e., $\sim 0.1 \mathrm{ppm} \mathrm{SRP,} \sim 0.08 \mathrm{ppm} \mathrm{NO}_{\mathrm{x}}-\mathrm{N}$, and $\sim 0.2 \mathrm{ppm} \mathrm{NH}_{4}{ }^{+}-\mathrm{N}$ ); cores treated with DI were expectedly lower for all nutrients at the start of the experiment (i.e., 0 ppm SRP, 0.058 ppm $\mathrm{NO}_{\mathrm{x}}-\mathrm{N}$, and $0.071 \mathrm{ppm} \mathrm{NH}_{4}{ }^{+}$-N; Fig. 4). Core water column pH was similar between treatment groups $(\mathrm{pH} 7.5-8)$ throughout the experiment. Agitated cores had relatively high DO levels compared to the other cores: up to $7.14 \mathrm{ppm}$ during agitation from lows of about 3.5 ppm during quiescence periods. Diffusion cores initially had DO levels of around 6 ppm, which steadily decreased over the $22 \mathrm{~d}$ experiment to $3 \mathrm{ppm}$. In the following, we describe changes in nutrient concentrations over the course of our experiment, and test the significance of these changes using $\mathrm{R}^{2}$ values.

\subsubsection{Advection Cores}

In the agitation group, intensive advective flux (195 rpm) along the SWI caused SRP to decrease to below detection within $6 \mathrm{~h}$ of the onset of the experiment, but $\mathrm{NO}_{\mathrm{x}}-\mathrm{N}$ and $\mathrm{NH}_{4}{ }^{+}-\mathrm{N}$ increased over the first five days of testing (to $1.769 \mathrm{ppm}$ and $1.025 \mathrm{ppm}$, respectively; Fig. 4). The $\mathrm{NO}_{\mathrm{x}}-\mathrm{N}$ increase was linear with time $\left(\mathrm{R}^{2}=0.92\right)$, whereas the $\mathrm{NH}_{4}{ }^{+}-\mathrm{N}$ trend was not $\left(\mathrm{R}^{2}=\right.$ 0.03). The subsequent 12-day period of no agitation resulted in a slight increase in SRP concentration to $0.035 \mathrm{ppm}\left(\mathrm{R}^{2}=0.59\right)$, a decrease in water column $\mathrm{NO}_{\mathrm{x}}-\mathrm{N}$ to $0.631 \mathrm{ppm}\left(\mathrm{R}^{2}=\right.$ $0.25)$, and no significant change in $\mathrm{NH}_{4}{ }^{+}-\mathrm{N}\left(\mathrm{R}^{2}=0.06\right)$. The second, five-day agitation period at a lower speed (65 rpm after an initial $2 \mathrm{~h}$ at $165 \mathrm{rpm}$ ) resulted in an initial decrease in SRP to below detection, followed by an increase to $0.030 \mathrm{ppm}\left(\mathrm{R}^{2}=0.25\right)$. The $\mathrm{NO}_{\mathrm{x}}-\mathrm{N}$ levels did not change significantly $\left(\mathrm{R}^{2}<0.01\right)$, whereas $\mathrm{NH}_{4}{ }^{+}-\mathrm{N}$ levels decreased to $0.305 \mathrm{ppm}\left(\mathrm{R}^{2}=0.61\right)$. 
The second period of no agitation saw a plateauing of SRP levels around $0.05 \mathrm{ppm}$, plateauing of $\mathrm{NO}_{\mathrm{x}}-\mathrm{N}$ around $1 \mathrm{ppm}\left(\mathrm{R}^{2}=0.24\right)$, and a decrease in $\mathrm{NH}_{4}{ }^{+}-\mathrm{N}$ to levels similar to pre-experiment concentrations $\left(0.113 \mathrm{ppm} ; \mathrm{R}^{2}=0.70\right)$. In terms of total dissolved $\mathrm{N}$, water column concentrations increased during the first agitation period, then steadily decreased for the rest of the experiment.

\subsubsection{Site Water Diffusion Cores}

SRP in site water diffusion cores showed three distinct periods of change in concentration (Fig. 4). In the first three days, SRP generally decreased from an initial concentration of 0.090 ppm to $0.046 \mathrm{ppm}\left(\mathrm{R}^{2}=0.59\right)$. In the following seven days, $\mathrm{SRP}$ increased to $0.104 \mathrm{ppm}\left(\mathrm{R}^{2}=\right.$ 0.75), then decreased for the last twelve days of the experiment $\left(\mathrm{R}^{2}=0.96\right)$ to $0.025 \mathrm{ppm}$. The average SRP concentration in the site water diffusion cores only dropped below $0.05 \mathrm{ppm}$ in days 3 and 22. The $\mathrm{NO}_{\mathrm{x}}-\mathrm{N}$ concentrations in the site water diffusion group increased linearly $\left(\mathrm{R}^{2}\right.$ $=0.84$ ) from $0.074 \mathrm{ppm}$ to $0.538 \mathrm{ppm}$ over 22 days. The $\mathrm{NH}_{4}{ }^{+}-\mathrm{N}$ concentration increased for the first four days $\left(\mathrm{R}^{2}=0.97\right)$, plateauing around $0.7 \mathrm{ppm}$ until day 22 , when levels dropped to below pre-experiment levels (i.e., $0.134 \mathrm{ppm})$. Total dissolved $\mathrm{N}$ increased linearly $\left(\mathrm{R}^{2}=0.76\right)$ from $0.262 \mathrm{ppm}$ to $1.186 \mathrm{ppm}$ over 16 days, and then decreased to $0.870 \mathrm{ppm}$ at the end of the experiment $\left(\mathrm{R}^{2}=0.28\right)$.

\subsubsection{Water Diffusion Cores}

DI water treatments resulted in a rapid, linear increase $\left(\mathrm{R}^{2}=0.95\right)$ in column water SRP from below detectable levels to $0.276 \mathrm{ppm}$ in the first seven days, then a decrease to $0.135 \mathrm{ppm}$ by the end of the 22-day experiment (Fig. 4). It took less than two days for the SRP concentration in the DI columns to go above the regulatory limit for total $\mathrm{P}$ in lakes (i.e., 0.05 
ppm; Illinois Environmental Protection Agency, 2016). Dissolved N concentrations in the DI cores increased linearly over 22 days: $\mathrm{NO}_{\mathrm{x}}-\mathrm{N}$ to $0.599 \mathrm{ppm}\left(\mathrm{R}^{2}=0.71\right)$ and $\mathrm{NH}_{4}{ }^{+}-\mathrm{N}$ to 1.190 ppm $\left(\mathrm{R}^{2}=0.82\right)$. Total dissolved $\mathrm{N}$ flux to the DI water columns continuously increased from $0.129 \mathrm{ppm}$ to $1.789 \mathrm{ppm}$ over 22 days $\left(\mathrm{R}^{2}=0.87\right)$. Based on RM-ANOVA, it was found that water column nutrient trends in the site water diffusion and DI diffusion cores over

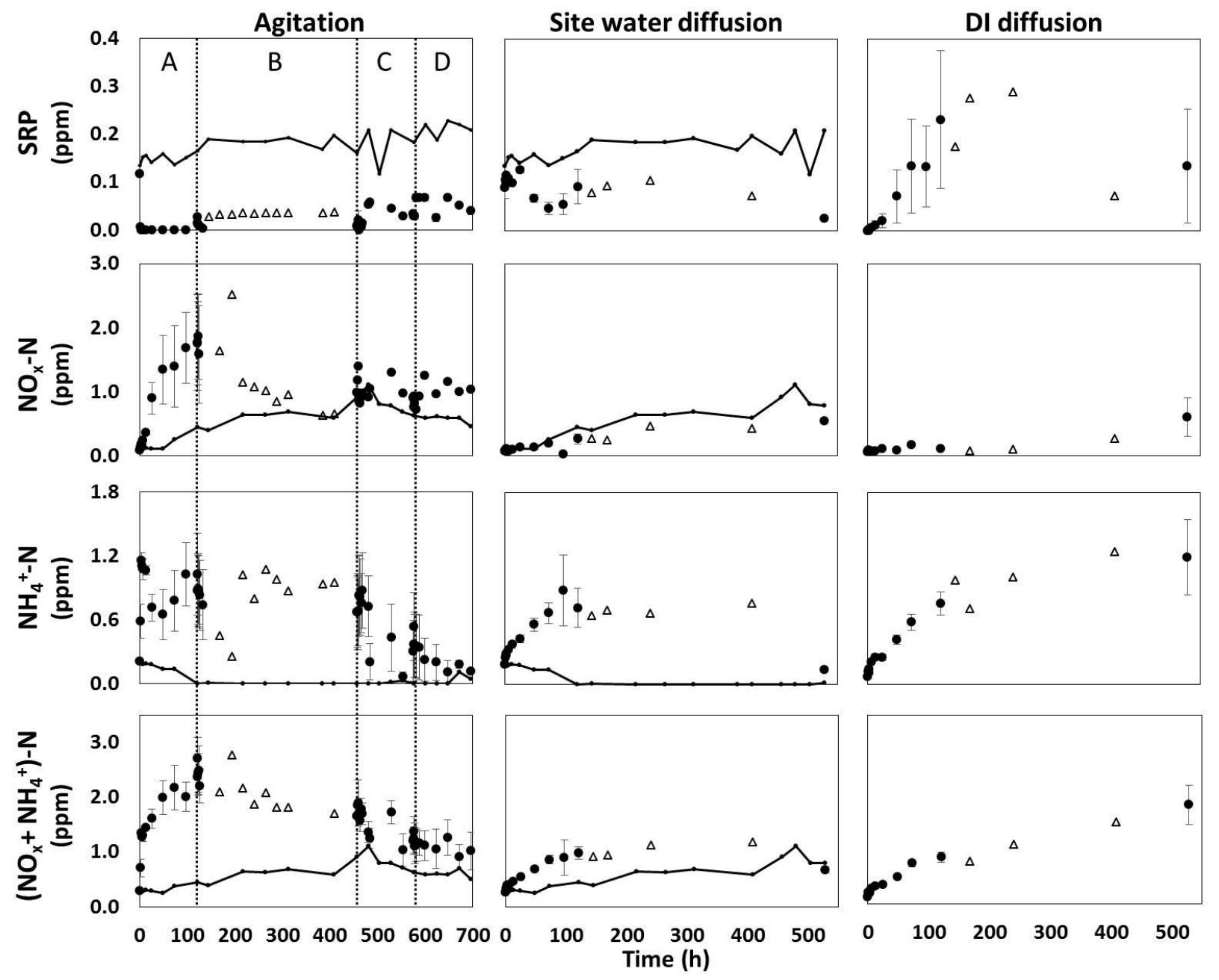

Figure 4. Plots showing core water column nutrient concentrations during the experiment. Dashed lines indicate changes in advection in the agitation group: A: $195 \mathrm{rpm}$ agitation, B: no agitation, C: $65 \mathrm{rpm}$ agitation after initial $2 \mathrm{~h}$ of $165 \mathrm{rpm}$, and D: no agitation. Black circles indicate five replicate samples of the water columns and standard error bars are shown. Open triangles indicate composited, acidified samples. The chemical composition of replacement lake water used to compensate for water volume loss due to sample collection in the agitation and site water diffusion groups is indicated with black lines. DI water ( $0 \mathrm{ppm}$ for all nutrients) was used to compensate for volume loss in the DI diffusion group. 
the course of the experiment were not significantly different $(\mathrm{p}=0.87,0.15$, and 0.52 for SRP, $\mathrm{NO}_{\mathrm{x}}-\mathrm{N}$, and $\mathrm{NH}_{4}{ }^{+}-\mathrm{N}$, respectively). In comparison, intense (195 rpm) agitation over the first 5 days of the experiment increased $\mathrm{NO}_{\mathrm{x}}-\mathrm{N}$ flux by at least $19 \times$ compared to diffusion treatments over the same time. Agitated cores showed $4 \times$ lower flux rates of $\mathrm{NH}_{4}{ }^{+}-\mathrm{N}$ compared to diffusion cores over the first 5 days but the total $\mathrm{N}$ flux in agitated cores was about $2 \times$ greater than the diffusion core treatments due to the higher $\mathrm{NO}_{\mathrm{x}}-\mathrm{N}$ flux. Differences in flux rates were evaluated by comparing the slopes of the linear regressions for the time period and nutrients of interest.

\subsubsection{Core Replacement Water}

The replacement water trends for each measured nutrient are shown in Fig. 4. Highfrequency sampling resulted in $496 \mathrm{~mL}$ of column water being removed and replaced from each agitation core over $29 \mathrm{~d}$. This represents a greater volume than the original water column (383 $\mathrm{mL}$ ). Diffusion experiment cores had $144 \mathrm{~mL}$ of water removed and replaced over $22 \mathrm{~d}$. Thus, the agitation cores lost $0.012 \mathrm{mg}$ SRP and $0.810 \mathrm{mg} \mathrm{N}$ through sample collection and gained $0.086 \mathrm{mg} \mathrm{SRP}$ and $0.284 \mathrm{mg} \mathrm{N}$ through water replacement for a net gain of $0.074 \mathrm{mg}$ SRP and a net loss of $0.526 \mathrm{mg}$ N. Site water diffusion cores experienced a net increase of $0.011 \mathrm{mg}$ SRP (0.023 mg added; $0.012 \mathrm{mg}$ removed) and a net loss of $0.034 \mathrm{mg} \mathrm{N}$ (0.064 mg added; $0.098 \mathrm{mg}$ removed). Therefore, the replacement lake water was SRP-enriched and N-depleted relative to the sediments. Nevertheless, a RM-ANOVA showed that replacement lake water and the site water core group had significantly different nutrient concentrations throughout the 22-day

experiment ( $\mathrm{p}<0.006$ for $\mathrm{SRP}, \mathrm{NO}_{\mathrm{x}}-\mathrm{N}$, and $\left.\mathrm{NH}_{4}{ }^{+}-\mathrm{N}\right)$, indicating that endogenous input of nutrients from the sediments was controlling the nutrient levels and trends of the cores, not the 
addition of replacement lake water. Samples removed from DI diffusion cores resulted in a loss of $0.017 \mathrm{mg}$ SRP and $0.085 \mathrm{mg} \mathrm{N}$.

\subsubsection{Core Sedimentary Nutrients and Metals}

At the end of the experiment, treated core sediments had significantly lower extractable $\mathrm{NO}_{\mathrm{x}}-\mathrm{N}$ in the top $5 \mathrm{~cm}$ of sediment (2.56-2.86 mg/kg less) compared to untreated cores (Fig. 5).
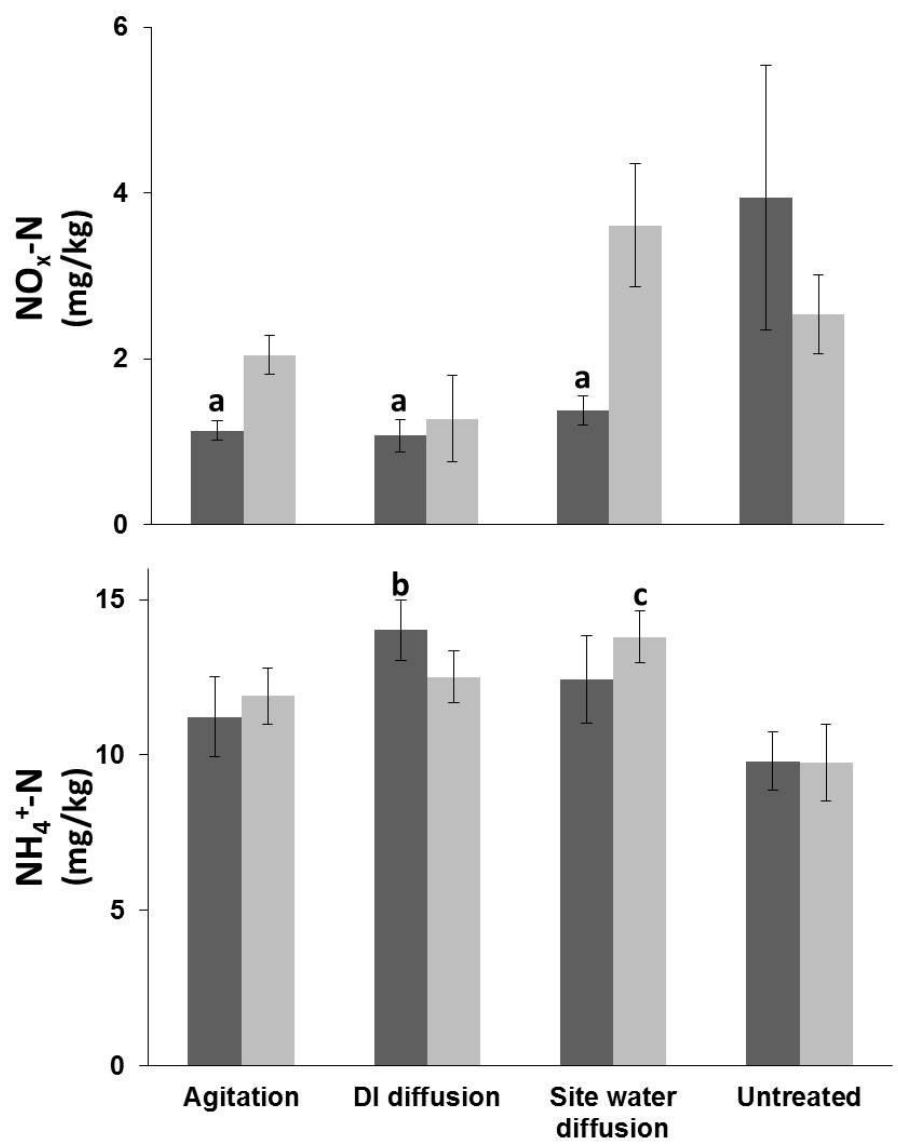

Figure 5. $\mathrm{KCl}$-extractable $\mathrm{NO}_{\mathrm{x}}-\mathrm{N}$ (top) and $\mathrm{NH}_{4}{ }^{+}-$ $\mathrm{N}$ (bottom) for each core group. Dark gray bars are for core sections $0-5 \mathrm{~cm}$ deep and light gray bars represent core sections at $5+\mathrm{cm}(<10 \mathrm{~cm}$ deep). Lowercase letters indicate a significant difference $(\mathrm{p}<0.05)$ in extractable $\mathrm{N}$ species relative to untreated (control) cores: $\mathrm{a}=0.02, \mathrm{~b}=<0.01, \mathrm{c}=$ 0.05 . Standard error bars are shown.
Extractable $\mathrm{NH}_{4}{ }^{+}-\mathrm{N}$ in the top $5 \mathrm{~cm}$ was significantly higher in the DI group compared to untreated samples (4.22 mg/kg more), but there were no significant differences between untreated samples and the other two treatment groups in the top $5 \mathrm{~cm}$ (Fig. 5). Site water diffusion core sediments below $5 \mathrm{~cm}$ depth had significantly more extractable $\mathrm{NH}_{4}{ }^{+}-\mathrm{N}(2.56 \mathrm{mg} / \mathrm{kg}$ more $)$ compared to untreated sediments, but there were no significant differences between the untreated cores and other two treatment cores for the deeper sediments. Extractable SRP was below detection for all treatment groups for both the $0-5 \mathrm{~cm}$ and $5+\mathrm{cm}$ sections of the cores. Sedimentary total P, total $\mathrm{C}$, and total $\mathrm{N}$ levels were not significantly different between treatment groups and compared to untreated cores. In the upper $5 \mathrm{~cm}$ of core 
sediments, mean total $\mathrm{P}$, total $\mathrm{C}$, and total $\mathrm{N}$ for all treatment groups were $500 \mathrm{mg} / \mathrm{kg}, 3.7 \mathrm{~g} / \mathrm{kg}$, and $0.4 \mathrm{~g} / \mathrm{kg}$, respectively. These values were not significantly different from the average total $\mathrm{P}$, total $\mathrm{C}$, and total $\mathrm{N}$ in the deeper $5+\mathrm{cm}$ samples. The mean sedimentary Fe concentration in the upper $5 \mathrm{~cm}$ of cores was $14,338 \mathrm{mg} / \mathrm{kg}$, which represents higher concentrations than $\mathrm{Al}(3,878$ $\mathrm{mg} / \mathrm{kg})$ and $\mathrm{Ca}(1,092 \mathrm{mg} / \mathrm{kg})$. We consider our total sedimentary Fe data a proxy for mineralogical analysis (i.e., for the presence of $\mathrm{Fe}$ oxy(hydr)oxides). $\mathrm{Fe}, \mathrm{Al}$ and $\mathrm{Ca}$ levels were not significantly different among cores.

\subsubsection{Turbidity, TSS, and Nutrient Concentration}

Based on the turbidity-TSS relationship (Fig. S1), the TSS concentration during our simulated storm conditions was as high as $190 \mathrm{~g} / \mathrm{L}$ (>11,000 NTU). The turbidity levels in the water columns of the site water and DI groups were negligible $(<12 \mathrm{NTU})$ as they were not subject to any agitation. Linear regressions between TSS and nutrient concentration showed a strong positive relationship in agitated cores between TSS and $\mathrm{NO}_{\mathrm{x}}-\mathrm{N}$ levels $\left(\mathrm{R}^{2}=0.93\right)$ during the first high-speed agitation period, but there was not a strong correlation between TSS and SRP or $\mathrm{NH}_{4}{ }^{+}-\mathrm{N}\left(\mathrm{R}^{2}<0.15\right)$. The second period of agitation showed no relationship between TSS and nutrient levels $\left(\mathrm{R}^{2}<0.1\right)$. In comparison, lake SRP and $\mathrm{NO}_{\mathrm{x}}-\mathrm{N}$ levels were significantly and positively correlated to turbidity (Table 1), while $\mathrm{NH}_{4}{ }^{+}$-N levels in the lake appeared to be unrelated to turbidity.

\section{Discussion}

\subsection{Spatial Distributions of Nutrients in an Impacted Reservoir}

Our extensive spatial sampling of water and sediments across a eutrophic, agricultural reservoir demonstrate several important trends in nutrients. Sedimentary total P concentrations in 
Carlyle Lake were highest towards the dam wall rather than near the inlet of the lake where the incoming Kaskaskia River delivers predominantly agriculturally derived runoff. We also observed increasing levels of total $\mathrm{C}$ and $\mathrm{OM}$ towards the dam wall. Based on the strong correlations between sedimentary total $\mathrm{P}$, total $\mathrm{C}$, and $\mathrm{OM}$, and the fact that all three are lower in the upper lake, we surmise that the total P signature is related to differences in OM deposition processes across the lake. In the upper lake, OM deposition may be more limited or "diluted" by high inorganic sediment deposition from the incoming Kaskaskia River. In other words, the relative percent of OM may be lower due to burial with coarse inorganic sediments settling as system transitions from lotic to lentic (e.g. Schleiss, 2013). Conversely, in the lower lake, where inorganic sediment deposition is likely lower, OM, and therefore total $\mathrm{P}$, increases. This is reflected by the similarly distributed regions of high concentrations of total $\mathrm{P}$, total $\mathrm{C}$, and $\mathrm{OM}$ (Fig. 3).

In addition to declining sediment deposition towards the dam, we speculate that the patterns we observed in total $\mathrm{P}$, total $\mathrm{C}$, and $\mathrm{OM}$ may also be related to changes in the grain size of sediments deposited across the reservoir. Our study did not include grain size analyses, but we suspect that coarser sediments are deposited near the inlet of reservoir as water velocity decreases, and finer suspended sediments are transported across a reservoir, some of which are eventually deposited near the dam (Schleiss, 2013). Indeed, during sampling, we observed that sediments in the upper lake were generally sandier in texture than those in the lower portion of the reservoir. These finer sediments near the dam may have higher clay content that could also play a role in $\mathrm{P}$ accumulation via surface exchange sites.

We did not observe the same trend for total $\mathrm{N}$ as we did for total P, total C, and OM (i.e., increasing concentrations in sediments towards the dam wall. Instead, the high concentrations of 
total $\mathrm{N}$ were observed near the North Fork and East Fork tributaries. This pattern may reflect additions of higher $\mathrm{N}$ content due to differing land use in the North Fork and East Fork watersheds. Indeed, these tributaries generally featured higher forested land cover (which immobilizes $\mathrm{N}$ at greater rates than agricultural land; $\mathrm{Xu}$ and $\mathrm{Xu}, 2015$ ) compared to the main stem of the Kaskaskia.

The large stores of $\mathrm{P}$ we observed in the sediments may provide context for historical US Army Corps of Engineers observations of Carlyle Lake's water chemistry, where P concentrations are often $>0.05 \mathrm{ppm}$, the benchmark for eutrophication. In detail, stored 'legacy' $\mathrm{P}$ in the surface sediments and porewaters may act as a persistent source to the water column over long time periods (Sharpley et al., 2013). For example, sediments near the dam wall exhibited the highest total P levels observed in the study (i.e., over 1,600 mg/kg), and corresponding water column P levels were likewise elevated relative to the rest of the lake at 0.1 ppm (Figs. 2, 3). 
The sedimentary nutrient level we observed across the reservoir are likely influenced by periodic pulses of nutrient-rich flood waters to the lake. When lake levels were low (i.e., during the May sampling event), nutrients in the water column were generally lower and homogeneous across the lake (Fig. 2). However, we observed that waters high in nutrients are imported from surrounding tributaries after rain events (seen during the June 2015 flood event; Fig. 2), which has been observed elsewhere (e.g. Michalak et al., 2013). These excess nutrients may be assimilated by algae and other organisms (discussed in detail in Section 5.3), leading to the high levels of total P, total C, total $\mathrm{N}$, and $\mathrm{OM}$ stored in the sediments, adding to the large internal $\mathrm{P}$ and $\mathrm{N}$ pools illustrated in Fig. 3.

\subsection{Advection- Versus Diffusion-Driven Nutrient Fluxes Along the SWI in Reservoirs}

Contrary to previous findings in the literature (Zhu et al., 2005; You et al., 2007; Dunne et al., 2012; Hirsch, 2012), where intense storm events and flood pulses have been shown to stimulate exponentially higher SRP export from sediments to lake waters, we found that intense agitation applied to intact sediment cores caused SRP to decrease in the overlying water column. The depletion of SRP can be explained by scavenging of SRP by Fe minerals in sediments, underlining the importance of Fe redox in reservoir P dynamics (e.g., Moore and Reddy 1994). In fact, the ratio of sedimentary Fe to total P in the core sediments ( 28.7) is above the threshold established by Jensen et al. (1992) for P retention under aerobic conditions. If this ratio holds true across the reservoir, internal P loading could be controlled by keeping surficial sediments oxidized. The presence of $\mathrm{OM}$ can also enhance the sorptive capacity of sedimentary $\mathrm{Fe}$ and $\mathrm{Al}$ by increasing the overall negative charge of clays (Łukawska-Matuszewska et al., 2013).

However, the results of our core study should be interpreted with the understanding that they are based on sediments from a single location where the total P content was below the lake average. 
Nevertheless, if the sedimentary Fe levels observed in the cores are similar throughout the lake, Fe redox likely plays a great role in controlling SRP levels in the water column.

Our results are in line with the findings of Fitzgerald (1970), who observed that muds from large Wisconsin lakes, including Lake Mendota (which, additionally, had comparable sedimentary Fe levels to those observed in this study; Nriagu, 1967), could sorb a large amount of SRP under aerobic conditions. Vincente et al. (2010) found that two adjacent lakes demonstrated the importance of $\mathrm{Fe}$ in sediments, where the lake with higher sedimentary $\mathrm{Fe}$ oxy(hydr)oxides than its neighbor acted as a SRP sink in response to sediment resuspension, while the lake with lower Fe released SRP under similar conditions.

While we did not measure redox conditions directly during our agitation experiment, lakebed sediments were almost certainly experiencing reducing conditions. This is suggested by several observations: (1) higher DO concentrations in the water column during agitation periods, (2) higher extractable $\mathrm{NH}_{4}{ }^{+}-\mathrm{N}$ but lower extractable $\mathrm{NO}_{x}-\mathrm{N}$ in unagitated core sediments (i.e., dissimilatory nitrate reduction to ammonium), and (3) changes in sediment color (from light gray to orange) once sediments were agitated, likely leading to $\mathrm{P}$ co-precipitation with Fe(hydr)oxides upon contact with Fe-bearing sediments compared to other elements known to bind P (e.g., $\mathrm{Ca}$ and $\mathrm{Al}$; Li et al., 2012).

$\mathrm{P}$ recalcitrance during resuspension into an oxygenated water column indicates a nonapatite, inorganic (i.e., not Ca-associated) form of P (Łukawska-Matuszewska et al., 2013). Interestingly, we observed the opposite relationship between turbidity (a proxy for suspended sediments that likely contain Fe able to bind P) and SRP in the field versus the lab. This could be the result of differences in the suspension mechanisms. In our lab experiment, sediments were 
suspended into the water column from intact lakebed samples due to controlled agitation. However, in the field sediments may have been in suspension for long periods of time and sourced from a different area in the lake rather than at the location of interest. In the field, we assume that the suspended sediments were in equilibrium with the aerobic lake water, and thereby unable to bind additional $\mathrm{P}$ to Fe-bearing minerals, hence the positive relationship between SRP and turbidity. However, in our lab experiments, the sediments were likely largely anoxic prior to agitation, and therefore had the potential to bind $\mathrm{P}$ to Fe-minerals, therefore causing a negative correlation between turbidity and SRP level.

By contrast, diffusive conditions favored reductive SRP release from Fe-(hydr)oxide minerals. Although diffusion core water column DO levels were fairly consistent throughout the experiment (3-5 ppm), sediment pore waters were likely anoxic as sediments become rapidly anoxic with depth in stagnant conditions. Therefore, the diffusion of SRP from sediments could be important for algal proliferation. Based on our results, we assume that inorganic sedimentary P mobility is likely to be predominantly controlled by Fe dynamics, and will therefore be more sensitive to changing redox conditions: releasing $\mathrm{P}$ under anoxic conditions and storing $\mathrm{P}$ during resuspension in an oxic water column. Although $\mathrm{KCl}$-extractable SRP in core sediments was below detection (even though total P levels were approximately $500 \mathrm{mg} / \mathrm{kg}$ in the upper $5 \mathrm{~cm}$ of core sediments), the $\mathrm{KCl}$-extractable SRP detection limit ( $0.04 \mathrm{ppm})$ may have been too high for our applications: a flux of less than $0.04 \mathrm{ppm}$ SRP from porewaters would have been a significant contribution to the water column, which exhibited detectable concentrations as low as $0.006 \mathrm{ppm}$.

It is important to note that SRP scavenging via resuspended sediment has never been described previously in a reservoir with agriculture land practices as intensive as observed at our 
study site. Most studies that have described such P dynamics were investigations of natural lakes, including glacial lakes (Fitzgerald, 1970; Peters and Cattaneo, 1984), an endorheic glacial basin (Gunatilaka, 1978), and hypersaline coastal lakes (Vincente et al., 2010). A study by de Groot (1981) of a manmade Dutch lake within the Rijnland boezem system (altered through peat mining, water diversion, agriculture, and more recently, tile drainage; Hooghoudt, 1952; Rijnlandwater control board, 2009) found that sediments acted as a sink for P (de Groot, 1981). Nevertheless, this system is not a river impoundment, and the surroundings featured only a fraction of the agricultural land use and tile drainage observed in our study in terms of watershed size. Indeed, our study site in the Midwestern US "Corn Belt" features phosphate-intensive fertilizer application and extensive tile drainage (Yaeger et al., 2013). As much as $82 \%$ of the upper Kaskaskia River watershed contains tile-drained land (Yaeger et al., 2013), conduiting nutrient-rich water and sediments to streams and reservoirs. Moreover, our site is a reservoir system, which have been shown to alter landscape-scale biogeochemical processes (e.g., Friedl and Wüest, 2002; Powers et al., 2013; Grantz et al., 2014). Our investigation is especially pertinent as population centers in rural areas expand, increasing the reliance on impounded water sources like Carlyle Lake.

In addition to water column depletion of $\mathrm{P}$, the agitation group cores exhibited elevated $\mathrm{N}$ concentrations and extreme turbidity levels due to the simulated storm events (up to 11,000 NTU compared to mean in situ turbidity levels of $455.3 \mathrm{NTU}$ ), thus representing the importance of advective flux due to extreme wind events on short-term nutrient export and storage, and, by extension, ecological health (e.g. Hirsch, 2012). High turbidity levels were due to extensive sediment disturbance: we observed distinct banding develop in the upper 2-3 cm of the agitation cores. High $\mathrm{N}$ export during agitation (over an order of magnitude larger than diffusive flux) was 
likely due to sediment disturbance that brought up stored $\mathrm{N}$ in porewaters and on exchange sites from the top few centimeters of lakebed sediments. $\mathrm{NO}_{\mathrm{x}}-\mathrm{N}$ and $\mathrm{NH}_{4}{ }^{+} \mathrm{N}$ levels plateaued as the agitation experiment progressed (Fig. 4), implying that the majority of bioavailable $\mathrm{N}$ was fluxed out of the sediment during the first agitation period, and subsequently volatilized via denitrification and/or assimilated into microbial biomass. Indeed, we observed marked depletion in extractable $\mathrm{NO}_{\mathrm{x}}-\mathrm{N}$ reserves in all treatment groups (Fig. 5), attesting to the mobility of N. It is therefore likely that the reservoir may experience large $\mathrm{N}$ removal, perhaps similarly to another impoundment of the Kaskaskia River upstream of Carlyle Lake (David et al., 2006).

Nevertheless, based on our experimental results, N-limited algae would benefit under both advective and diffusive conditions, as both mechanisms resulted in high inputs of $\mathrm{N}$ to the water column from the sediment. Pulses of endogenous $\mathrm{N}$ to the water column could be especially important during late summer, when algal dynamics are N-limited due to low levels of dissolved $\mathrm{N}$ species (Chaffin et al., 2013).

Our core study demonstrated that in addition to short-term nutrient reserves in sediments, our agricultural reservoir may also have substantial, long-term endogenous reserves of $\mathrm{P}$ and $\mathrm{N}$ : after $29 \mathrm{~d}$, total sedimentary $\mathrm{P}$ and $\mathrm{N}$ did not change significantly. Therefore, it appears that nonextractable sedimentary reserves of $\mathrm{P}$ and $\mathrm{N}$ were not affected by short-term advective and diffusive processes. Based on the large reserves of total $\mathrm{P}$ and $\mathrm{N}$ relative to the amounts released during advection or diffusion, we posit that Carlyle Lake, and by extension, reservoirs in similar agricultural settings, could self-supply nutrients for algae without further external input over longer timescales. 


\subsection{The Interrelationship of Algae and Lake Nutrient Dynamics: a Self-Perpetuating}

\section{Bloom?}

Our study exemplifies how impacted lakes and reservoirs may undergo algal "forcing" of diffusion gradients: algae assimilate nutrients that enter the lake from nutrient-rich flood waters and storm-driven $\mathrm{N}$ pulses from lakebed sediments until the water column is depleted. Once the lake water is depleted in nutrients, diffusion is enhanced by the presence of a relatively depleted water column compared to the $\mathrm{P}$ - and $\mathrm{N}$-enriched porewaters and sediments, thus allowing more algal growth. Indeed, we observed increased P and N concentrations in our diffusion cores (Fig. 4) that may represent persistent SRP (Søndergaard et al., 2013) and $\mathrm{NO}_{\mathrm{x}}-\mathrm{N}$ loading to the nutrient-depleted water columns of shallow lakes in summer.

A considerable amount of $\mathrm{P}$ can be taken up by microorganisms in oxic conditions and transformed to cell biomass, particularly polyphosphate, which is the stored form of $\mathrm{P}$ in microbial cells (Huang et al., 2011). This phenomenon would both encourage continued flux of P to the water column via diffusion, and return $\mathrm{P}$ to the sediment as algae die and fall to the lake bottom. Though not observed in this study, anoxia induced through algal die-offs after blooming could allow Fe-bound P to be released into the water column (Zhou et al., 2013), perpetuating a positive feedback mechanism for continued algal growth.

Additionally, $\mathrm{P}$ desorption from the sediment can be stimulated through algal photosynthesis, which raises the $\mathrm{pH}$ of the water column through $\mathrm{CO}_{2}$ removal: a $\mathrm{pH}$ of 8 or 9 (commonly encountered in the lake during sampling) favors $\mathrm{P}$ release via ligand exchange reactions from suspended sediment particles consisting of Fe-(hydr)oxides (Jensen and Andersen, 1992). In spatial surveys of Carlyle Lake, we observed a positive correlation between DO and chlorophyll concentration and negative correlations between $\mathrm{pH}$ and nutrients, implying 
that where algae were photosynthesizing and removing $\mathrm{CO}_{2}$ from the water column, they were also taking up nutrients and raising $\mathrm{pH}$ (Table 1). These relationships confirm an algal influence on lake $\mathrm{pH}$ and nutrient levels. However, $\mathrm{pH}$ alone did not favor nutrient storage or release in the mesocosms: cores were near-neutral in $\mathrm{pH}$ as we prevented algal growth by storing cores in the dark. In terms of $\mathrm{N}$ dynamics, DO is important: oxygen levels rose during simulated storm pulses, which resulted in higher releases of $\mathrm{NO}_{\mathrm{x}}-\mathrm{N}$, i.e., the oxidized form of $\mathrm{N}$, compared to undisturbed diffusion cores, which released more $\mathrm{NH}_{4}{ }^{+}-\mathrm{N}$ than $\mathrm{NO}_{\mathrm{x}}-\mathrm{N}$. The predominance of $\mathrm{NO}_{\mathrm{x}}-\mathrm{N}$ in July lake water samples was likely due to aeration during flooding (Fig. 2).

In situ measurements of Carlyle Lake's algal activity (measured as chlorophyll concentration) was found to be highly correlated with low nutrient levels. High lake primary productivity in May could have depleted the water column of nutrients through algal growth and assimilation of $\mathrm{N}$ and $\mathrm{P}$, which were conditions we sought to replicate in the DI diffusion core experiment. As the site water and DI diffusion treatments did not significantly differ in terms of overall nutrient flux, we could not quantify a diffusion flux rate to a depleted water column compared to a high-nutrient water column. It is likely that the site water itself was depleted relative to the sediment, which, assuming that the cores we collected were representative of the lake at large, had measurable pools of extractable $\mathrm{NO}_{\mathrm{x}}-\mathrm{N}$ and $\mathrm{NH}_{4}{ }^{+}-\mathrm{N}$ (Fig. 5).

During the June sampling event, floodwaters were characterized by $20 \times$ higher turbidity and $50 \%$ lower conductivity compared to water chemistry measured in May. We also observed $1.5 \times$ lower chlorophyll levels and higher levels of SRP $(6 \times), \mathrm{NO}_{\mathrm{x}}-\mathrm{N}(10 \times)$, and $\mathrm{NH}_{4}{ }^{+}-\mathrm{N}(1.3 \times)$. Due to the high nutrient levels recorded in the upper lake waters, it is likely that conditions were favorable for algal growth once turbidity decreased. Thus, flood pulses introduce nutrients to the lake that may be taken up by algae and/or stored. Additionally, algae imported from surrounding 
tributaries during a flood pulse may proliferate once they encounter the high nutrient, lower turbidity conditions of the lake (Conroy et al., 2008; Kane et al., 2014).

\section{Conclusions}

Analyses of the waters and sediments of a reservoir within an intensely managed landscape reveal a system that has been highly altered by agriculture: surface sediments (particularly those in deeper areas of the lake) are enriched in total $\mathrm{P}$, and could serve as a long-term endogenous nutrient source for algae, primarily through diffusive flux. We found that $\mathrm{P}, \mathrm{C}$, and OM-rich sediments accumulate towards the dam wall, and N-rich sediments accumulate closer to the inlet. We found that sediment resuspension in the lake promoted the storage of $\mathrm{P}$ in sediments, likely through adsorption onto Fe-bearing sediments. It is possible that similar bodies of water may be physically inclined towards P storage: Carlyle Lake's shallow depths means that the wave base is often in contact with the sediment, thus keeping surface sediments oxygenated, thereby promoting SRP scavenging through Fe oxidation. This may be an important factor controlling SRP levels in lacustrine systems in intensively managed landscapes. The export of bioavailable $\mathrm{N}$ species, particularly $\mathrm{NO}_{\mathrm{x}}-\mathrm{N}$, seems to be most efficient under advection conditions based on stimulated storm pulses in sediment core mesocosms. Diffusion was also highly important in observed $\mathrm{N}$ dynamics. Thus, our results indicate that algal activity could be favored under most conditions in the lake. Large inputs of $\mathrm{N}$ to the water column during advection due to a wind storm could stimulate algae, which would then assimilate the nutrients until the water column is relatively depleted. This depletion would then stimulate a diffusion gradient, where stored $\mathrm{N}$ and P could be drawn up and continue to feed algal blooms. Our characterization of the behavior of

nutrients under diffusive and advective conditions could allow reservoir managers to forecast the extent of nutrient release and the possible impacts on water quality and chemistry. 


\section{Acknowledgments}

We thank Kevin Slattery and Joe Smothers at US Army Corps of Engineers for their help in coordinating field activities for this project as well as boat access, and appreciate the help from boat operators Carlis Lairson, Daniel Kluemke, and Jordan Smith. We are grateful for help in the lab and field provided by Margaret Hennessey, Andrew Shaughnessy, Emily Deeba, Armahni Fearn, and Robert Wurth. We greatly appreciate Heather Robinson's help with field work and running the ICP-OES instrument. We thank Dr. Abuduwasiti Wulamu for his help with the spatial interpolation aspects of this study. ICP-OES analyses were performed at the Nano Research Facility (NRF) of Washington University, a member of the National Nanotechnology Infrastructure Network (NNIN), which is supported by the National Science Foundation under grant no. ECS-0335765. This project was funded by a Presidential Research Fund grant awarded to L.G. Chambers and other funding sources within Saint Louis University. 


\section{References}

Amirbahman, A., Lake, B.A., Norton, S.A., 2012. Seasonal phosphorus dynamics in the surficial sediment of two shallow temperate lakes: A solid-phase and pore-water study. Hydrobiologia 701, 65-77. doi:10.1007/s10750-012-1257-z

Amirbahman, A., Pearce, A.R., Bouchard, R.J., Norton, S. A., Kahl, J.S., 2003. Relationship between hypolimnetic phosphorus and iron release from eleven lakes in Maine, USA. Biogeochemistry 65, 369-385. doi:10.1023/A:1026245914721

Anderson, J. M., 1976. An ignition method for determination of total phosphorus in lake sediments. Water Res. 10, 329-331

Chaffin, J.D., Bridgeman, T.B., Bade, D.L., 2013. Nitrogen Constrains the Growth of Late Summer Cyanobacterial Blooms in Lake Erie. Adv. Microbiol. 3, 16-26. doi:10.4236/aim.2013.36A003

Chiang, L.-C., Yuan, Y., Mehaffey, Jackson, M., Chaubey, I., 2012. Assessing SWAT's performance inthe Kaskaskia River watershed as influenced by the number of calibration stations used. Hydrol. Process. 2274. doi:10.1002/hyp.9589

David, M.B., Wall, L.G., Royer, T. V., Tank, J.L., 2006. Denitrification and the nitrogen budget of a reservoir in an agricultural landscape. Ecol. Appl. 16, 2177-2190. doi:10.1890/10510761(2006)016[2177:DATNBO]2.0.CO;2

Ding, Y., Qin, B., Zhu, G., Wu, T., Wang, Y., Luo, L., 2012. Effects of typhoon Morakot on a large shallow lake ecosystem ,. Ecohydrology 5, 798-807. doi:10.1002/eco.270

Dorich, R.A., Nelson, D.W., Sommers, L.E., 1985. Estimating algal available phosphorus in suspended sediments by chemical extraction. J. Environ. Qual. 14, 400-405.

Dunne, E.J., Coveney, M.F., Marzolf, E.R., Hoge, V.R., Conrow, R., Naleway, R., Lowe, E.F., Battoe, L.E., 2012. Efficacy of a large-scale constructed wetland to remove phosphorus and suspended solids from Lake Apopka, Florida. Ecol. Eng. 42, 90-100.

doi:10.1016/j.ecoleng.2012.01.019

Einsele W. 1936. Uber die Beziehungen des Eisenkreislaufs zum Phosphatkreislauf im Eutrophen See. Arch Hydrobioa. 29:664-86

Fisher, M.M., Brenner, M., Reddy, K.R., 1992. A simple inexpensive piston corer for collecting undisturbed sediment. J. Paleolimnol. 157-161.

Grantz, E.M., Haggard, B.E., Scott, J.T., 2014. Stoichiometric imbalance in rates of nitrogen and phosphorus retention, storage, and recycling can perpetuate nitrogen deficiency in highlyproductive reservoirs. Limnol. Oceanogr. 59, 2203-2216. doi:10.4319/lo.2014.59.6.2203

Grunwald, S., Corstanje, R., Weinrich, B.E., Reddy, K.R., 2006. Spatial patterns of labile forms of phosphorus in a subtropical wetland. J. Environ. Qual. 35, 378-89. doi:10.2134/jeq2005.0042 
Gunatilaka, A. Role of seston in the phosphate removal in Neusiedler See. Verh. Int. Ver. Limnol. 1978. 20:986-991.

Hirsch, R.M., 2012. Flux of Nitrogen, Phosphorus, and Suspended Sediment from the Susquehanna River Basin to the Chesapeake Bay during Tropical Storm Lee, September 2011, as an indicator of the effects of reservoir sedimentation on water quality. U.S. Geol. Surv. Sci. Investig. Rep. 2012-5185 17.

Hooghoudt, S. 1952. Tile drainage and subirrigation. Soil Science. 75:34-38.

Huang, L., Du, S., Fan, L., Lin, X., Wang, H., Zhang, Y., 2011. Microbial activity facilitates phosphorus adsorption to shallow lake sediment. J. Soils Sediments 11, 185-193. doi:10.1007/s11368-010-0305-4

Illinois Department of Natural Resources, 2016. Carlyle Lake, Available from: http://www.ifishillinois.org/profiles/display_lake.php?waternum=00276 (Accessed 1 January 2016)

Illinois Department of Environmental Protection, 2016. Illinois Integrated Water Quality Report and Section 303(d) List - Volume I: Surface Water.

Illinois State Water Survey, 1975. Analysis of the operation of Lake Shelbyville and Carlyle Lake to maximize agricultural and recreation benefits.

Jensen, H.S., Andersen, F.Ø., 1992. Importance of temperature, nitrate, and $\mathrm{pH}$ for phosphate release from aerobic sediments of four shallow, eutrophic lakes. Limnol. Oceanogr. 37, 577-589. doi:10.4319/1o.1992.37.3.0577

Kelderman, P., van de Repe, A.M. 1982. Temperature dependence of sediment-water exchange in Lake Grevelingen, SW Netherlands. Hydrobiologia. 91: 489-500. doi:10.1007/PL00020037

Kane, D.D., Conroy, J.D., Peter Richards, R., Baker, D.B., Culver, D. A., 2014. Re-eutrophication of Lake Erie: Correlations between tributary nutrient loads and phytoplankton biomass. J. Great Lakes Res. 2005-2010. doi:10.1016/j.jglr.2014.04.004

Kilinc, S., Moss, B., 2002. Whitemere, a lake that defies some conventions about nutrients. Freshw. Biol. 47, 207-218. doi:10.1046/j.1365-2427.2002.00797.x

Kleinman, P., Sharpley, A., Buda, A., McDowell, R., Allen, A., 2011. Soil controls of phosphorus in runoff: Management barriers and opportunities. Can. J. Soil Sci. 91, 329-338. doi:10.4141/cjss09106

Kleinman, P.J. a, Sharpley, A.N., McDowell, R.W., Flaten, D.N., Buda, A.R., Tao, L., Bergstrom, L., Zhu, Q., 2011. Managing agricultural phosphorus for water quality protection: Principles for progress. Plant Soil 349, 169-182. doi:10.1007/s11104-011-0832-9

Li, J., Heap, A.D., 2008. A review of spatial interpolation methods for environmental scientists. Geosci. Aust. , Rec. 2008/23. 
Li, Y., Yu, S., Strong, J., Wang, H., 2012. Are the biogeochemical cycles of carbon, nitrogen, sulfur, and phosphorus driven by the "FeIII-FeII redox wheel" in dynamic redox environments? J. Soils Sediments 12, 683-693. doi:10.1007/s11368-012-0507-z

Michalak, A.M., Anderson, E.J., Beletsky, D., Boland, S., Bosch, N.S., Bridgeman, T.B., Chaffin, J.D., Cho, K., Confesor, R., Daloglu, I., Depinto, J.V., Evans, M.A., Fahnenstiel, G.L., He, L., Ho, J.C., Jenkins, L., Johengen, T.H., Kuo, K.C., Laporte, E., Liu, X., McWilliams, M.R., Moore, M.R., Posselt, D.J., Richards, R.P., Scavia, D., Steiner, A.L., Verhamme, E.,Wright, D.M., Zagorski, M.A., 2013. Record-setting algal bloom in Lake Erie caused by agricultural and meteorological trends consistent with expected future conditions. Proc. Natl. Acad. Sci. U. S. A. 110, 6448-6452. doi: 10.1073/pnas.1216006110

Moore, P.A.J., Reddy, K.R., 1994. Role of Eh and pH on Phosphorous Geochemistry in Sediments of Lake Okeechobee, Florida. J. Environ. Qual. 23, 955-964.

Mortimer, C.H., 1941. The exchange of dissolved substances between mud and water in lakes. Journal of Ecology 29, 280-329.

Nriagu, J.O., 1967. The distribution of iron in lake sediments. Wisconsim Acad. Sci. Arts Lett. 56, 153-164.

Paerl, H.W., Hall, N.S., Calandrino, E.S., 2011. Controlling harmful cyanobacterial blooms in a world experiencing anth opogenic and climatic-induced change. Sci. Total Environ. 409, 1739-1745. doi:10.1016/j.scitotenv.2011.02.001

Paerl, H.W., Paul, V.J., 2012. Climate change: Links to global expansion of harmful cyanobacteria. Water Res. 46, 1349-1363. doi:10.1016/j.watres.2011.08.002

Peters, R. H. \& A. Cattaneo, 1984. The effects of turbulence on phosphorus supply in a shallow bay of Lake Memphremagog. Verhandlungen der Internationalen Vereinigung für Limnologie 22: $185-189$

Powers, S.M., Robertson, D.M., Stanley, E.H., 2013. Effects of lakes and reservoirs on annual river nitrogen, phosphorus, and sediment export in agricultural and forested landscapes. Hydrol. Process. 28, 5919-5937. doi:10.1002/hyp.10083

Qin, B., Hu, W., Gao, G., Luo, L., Zhang, J. 2004. Dynamics of sediment resuspension and the concenptual schema of nutrient release in the large shallow Lake Taihu, China. Chinese Science Bulletin. 49, 54-64. doi: 10.1007/BF02901743

R Core Team, 2016. R: A language and environment for statistical computing. R Foundation for Statistical Computing, Vienna, Austria. ISBN 3-900051-07-0. URL http://www.Rproject.org/.

Reddy, K.R., Fisher, M.M., Ivanoff, D., 1996. Resuspension and diffusive flux of nitrogen and phosphorus in a hypereutrophic lake. J. Environ. Qual. doi:10.2134/jeq1996.00472425002500020022x

Reddy, K.R., Newman, S., 1992. Sediment resuspension effects on alkaline phosphatase activity. Hydrobiologia 75-86. 
Rijnland water control board. 2009. Flood control in the Netherlands. ISBN 978-90-72381-10-1 Available from: https://www.rijnland.net/downloads/floodcontrolrijnland-1-1.pdf (Accessed 11 December 2016).

Roy, E.D., Nguyen, N.T., Bargu, S., White, J.R., 2012. Internal loading of phosphorus from sediments of Lake Pontchartrain (Louisiana, USA) with implications for eutrophication. Hydrobiologia 684, 69-82. doi:10.1007/s10750-011-0969-9

Schleiss, A.J., 2013. Sedimentation of Reservoirs. Encyclopedia of Natutal Hazards: Encyclopedia of Earth Sciences Series. 901-905. doi: 10.1007/978-1-4020-4399-4_312

Sharpley, A., Jarvie, H.P., Buda, A., May, L., Spears, B., Kleinman, P., 2013. Phosphorus Legacy: Overcoming the Effects of Past Management Practices to Mitigate Future Water Quality Impairment. J. Environ. Qual. 42, 1308-1326. doi:10.2134/jeq2013.03.0098

Søndergaard, M., Kristensen, P., Jeppesen, E. 1992: Phosphorus release from resuspended sediment in the shallow and wind exposed Lake Arreso, Denmark. Hydrobiologia 228, 91- 99

Søndergaard, M., Bjerring, R., Jeppesen., E. 2013. Persistent internal phosphorus loading during summer in shallow eutrophic lakes. Hydrobiologia. 408, 145-152

Steffen, M.M., Zhu, Z., McKay, R.M.L., Wilhelm, S.W., Bullerjahn, G.S., 2014. Taxonomic assessment of a toxic cyanobacteria shift in hypereutrophic Grand Lake St. Marys (Ohio, USA). Harmful Algae 33, 12-18. doi:10.1016/j.hal.2013.12.008

Tammeorg, O., Horppila, J., Laugaste, R., Haldna, M., Niemistö, J., 2015. Importance of diffusion and resuspension for phosphorus cycling during the growing season in large, shallow Lake Peipsi. Hydrobiologia 760, 133-144. doi:10.1007/s10750-015-2319-9

Torres, I.C., Turner, B.L., Ramesh Reddy, K., 2014. The Chemical Nature of Phosphorus in Subtropical Lake Sediments. Aquat. Geochemistry 20, 437-457. doi:10.1007/s10498-0149228-9

US Army Corps of Engineers, 2006. 2006 Carlyle Lake Water Quality Report, Available from: http://www.mvs.usace.army.mil/Portals/54/docs/expertise/Ordnance_Technical/2006_Carly le_Lake_Annual_Report.pdf (Accessed 1 April 2015)

US Department of Agriculture, National Agricultural Statistics Service, Research and Development Division, Geospatial Information Branch, Spatial Analysis Research Section, 2015.

National Agricultural Statistics Service, 2014 Illinois Cropland Data Layer

US Department of Agriculture Natural Resources Conservation Services, National Cartography \& Geospatial Center, 2000. National Elevation Dataset 30 Meter 1-degree Tiles.

US Environmental Protection Agency, 2014. 303(d) Listed Impaired Waters 2014 National Extract, Office of Water.

US Environmental Protection Agency, 1993. Methods for the determination of inorganic substances in environmental samples. 
Vicente, I., L. Cruz-Pizarro, L., Rueda, F,J. 2010. Sediment resuspension in two adjacent shallow coastal lakes: controlling factors and consequences on phosphate dynamics. Aquatic Sciences. 72: 21-31.

Xie, L.Q., Xie, P., Tang, H.J., 2003. Enhancement of dissolved phosphorus release from sediment to lake water by Microcystis blooms - An enclosure experiment in a hyper-eutrophic, subtropical Chinese lake. Environ. Pollut. 122, 391-399. doi:10.1016/S02697491(02)00305-6

$\mathrm{Xu}, \mathrm{Y} ., \mathrm{Xu}, \mathrm{Z}$. 2015. Effects of land use change on soil gross nitrogen transformation rates in subtropical acid soils of Southwest China. Environ Sci Pollut Res. 22, 10850-10860. doi: $10.1007 / \mathrm{s} 11356-015-4262-8$

Yaeger, M. a., Sivapalan, M., McIsaac, G.F., Cai, X., 2013. Comparative analysis of hydrologic signatures in two agricultural watersheds in east-central Illinois: Legacies of the past to inform the future. Hydrol. Earth Syst. Sci. 17, 4607-4623. doi:10.5194/hess-17-4607-2013

You, B.S., Zhong, J.C., Fan, C.X., Wang, T.C., Zhang, L., Ding, S.M., 2007. Effects of hydrodynamics processes on phosphorus fluxes from sediment in large, shallow Taihu Lake. J. Environ. Sci. 19, 1055-1060. doi:10.1016/S1001-0742(07)60172-7

Zhang, J., Burke, P., Iricanin, N., Hill, S., Gray, S., Budell, R., 2011. Long-Term Water Quality Trends in the Lake Okeechobee Watershed, Florida. Crit. Rev. Environ. Sci. Technol. 41, 548-575. doi:10.1080/10643389.2010.530577

Zhou, Y., Obenour, D.R., Scavia, D., Johengen, T.H., Michalak, A.M., 2013. Spatial and temporal trends in Lake Erie hypoxia, 1987-2007. Environ. Sci. Technol. 47, 899-905. doi:10.1021/es303401b

Zhu, G., Qin, B., Gao, G., 2005. Direct evidence of phosphorus outbreak release from sediment to overlying water in a large shallow lake caused by strong wind wave disturbance. Chinese Sci. Bull. 50, 577-582. doi:10.1007/BF02897483 


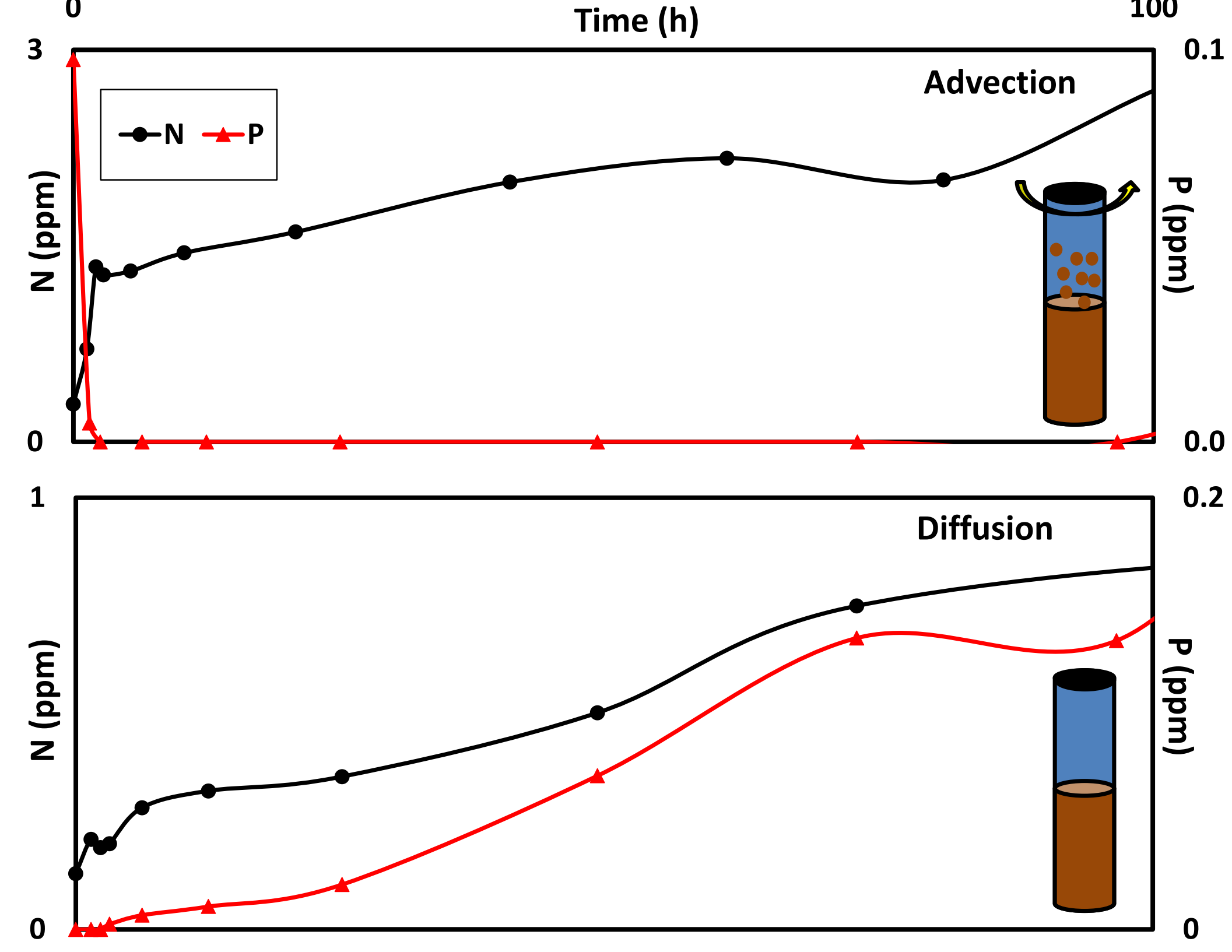

